been provided throughout for carrying out the tests under the right physical conditions. In choosing the tests the author has guarded, so far as possible, against the mutual interference of ions, and this is typical of the care he has taken throughout to ensure success to the user of his system of analysis.

A. C. C

\section{A Dictionary of the Fungi}

By Dr. G. C. Ainsworth and Dr. G. R. Bisby. Pp. viii +360. (Kew : Imperial Mycological Institute, 1943.) $20 s$.

FOLLOWING the lines of Willis's well-known 1 "Dictionary of Flowering Plants and Ferns", Ainsworth and Bisby have included in their 339 pages a mass of useful information. In addition to generic names, with a reference to the family and a brief note as to habitat, they have provided explanations of technical terms, though unfortunately without their derivations. Students with "little Latin and less Greek" may be puzzled, for example, to find under plano- both planogametes and planoconvex, even though the terms plane and planetism are defined in the preceding lines. Useful notes are given on some of the older mycologists, and such popular terms as devil's snuff box are not disdained.

It is perhaps inevitable that, in a work of this kind, detail should ke uneven. Thus under sex one learns that Pyronema-that classical fungus-has a trichogyne but not that it has an antheridium, though the non-motile sperms of the Laboulkeniacex are mentioned and both trichogyne and antheridium are illustrated in Fig. 54.

An interesting detail is that the book (apart from its appendix) is written in Basic English, but the simplicity which this suggests is lessened by the mass cf technical terms. Comparatively few of thcse who look up the meaning of metula will be much wiser when informed that it is "a sporophore branch having phialides". It could be described nearly as briefly as "a branch bearing spores on flask-shaped outgrowths". 'The explanation of even superfluous technical terms may be of value, but their use is to be deprecated. Mycology is burdened with far too extensive a vocabulary, and the only serious criticism of this convenient little book is that it may revive words which were mercifully becoming obsolete.

\section{Map Projections by Practical Construction}

By A. Hinckley. Pp. 84. (London: George Philip and Son, Ltd.; Liverpool: Philip, Son and Nephew, Ltd., 1942.) $3 s$.

GOR students of limited mathematical ability, books on map projections usually have an arid and unattractive appearance. This little bookwhich assumes only an elementary knowledge of mathematics and provides simple practical constructions for a large number of projections, together with many exercises that bring out the value for many purposes of the study of the subject-is notably unusual in its treatment, and has the commendation of no less an authority than the secretary of the Royal Geographical Society. There is no doubt that the teacher of mathematics or geography-especially of the former-who is reasonably emancipated from examination limitations, will find in this book ample scope for much valuable work, and any student who follows it diligently will not only solvo a large number of interesting mathematical problems but also acquire a considerable practical knowledge of the geographical applications of the study of map projections.

For the student of geography, who is primurily concerned with the selection of the most appropriate projection for any particular geographical pur pose, the book is, however, somewhat limited in keing severely practical. Both teacher and student would appreciate a clear preliminary presentation of the problems involved in mapping the gloke, and a systematic discussion of the relative value of different projections for different purposes, in addition to the incidental comments that are found in the took. At the same time it is recognized that the numerous excellent exercises cover a wide range of matters of interest and importance to the geographer.

\section{S. S.}

Simple Experiments in Biology

Compiled by Cyril Bibby. Pp. xiit 164. (London and Toronto: William Heinemann, Ltd., 1943.) 7s. $6 d$.

THE author of this useful book is education oificer of the Central Council for Health Education, and joint editor of Biology. He is therefore very well acquainted with the practical needs of biology teachers, and the guidance they require. No specialized knowledge on the part of the teacher is assumed and no expensive apparatus for experiments is required.

The book is essentially practical ; the theory being left to the more orthodox text-books. Descriptions are explicit, and the whole course is comprehensive. The only criticism we have is that, although there may be several reasons for not inserting an index in this type of book, we still think its omission is to be deplored.

It is doubtful if there is any other book quite like this, and we would strongly recommend its adoption in all classes of biology up to, and including, school certificate standard.

\section{Hermaphroditos}

The Human Intersex. By Dr. A. P. Cawadias. Pp. ix $+78+9$ plates. (London: William Heincmann (Medical Books), Ltd., 1943.) I5s. net.

$7 H E$ intersex or free martin has always been a subject of great interest in medicine, in literature and in mythology. Dr. A. P. Cawadias develops his scheme of classification of androgynoids and gynandroids from a basic description of the physiology of sex formation and of the physio-pathology of intersexuality. Case-histories and illustrations of the various types of abnormalities are given, and there are some notes on the lines of treatment.

\section{Studies on Immunisation}

First Series. By Sir Almroth E. Wright. (Researches from the Inoculation Department, St. Mary's Hospital, London, W.2, Vol. 3.) Pp. xi +421. (London": William Heinemann (Medical Books), Ltd., 1943.) 25s. net.

THIS third volume in a series of the collected rescarches of Sir Almroth Wright contains reprints of papers on work done in the first decade of this century and originally published in 1909 . The survey covers the antibacterial elcments of the blood fluids, agglutinins, bactericidins and opsonins, and proceeds to vaccine and serum therapy. 